PAULINA TOTA*

\section{Miasto inteligentne - miasto dostępne. Nowoczesne technologie miejskie w kontekście projektowania uniwersalnego}

Smart City - Accessible City. Newest urban technologies as a framework of universal design

Streszczenie

Zmiany demograficzne, jakie możemy obecnie odnotować w społeczeństwie, mają charakter bezprecedensowy: jeszcze nigdy w historii liczba mieszkańców naszego świata nie powiększała się tak gwałtownie a jednocześnie - średnia wieku ludności nie była tak wysoka. Szacuje się, że już w tym momencie grupa osób powyżej sześćdziesiątego roku życia to około 500 $1 / 5$ catej populacji.

Istnieje wiele definicji miasta inteligentnego: różnią się one rozłożeniem akcentów - jedne z nich zwracają uwage gtównie na kwestie technologiczne, inne - na zagadnienia społeczne. Współtzesne miasta coraz częściej wykorzystują inteligentne rozwiązania i technologie, a miarą ich racjonalnego stosowania jest wskaźnik jakości życia mieszkańców. Co istotne - wszystkich
mieszkańców, niezależnie od ich możliwości i sprawności. Z dużą pewnością założyć można, że miasto inteligentne jest więc miastem dostępnym i przyjaznym.

Artykuł ma na celu analizę tych spośród stosowanych rozwiązań i polityk miejskich wspótczesnych smart cities, które w bezpośredni sposób wpływają na jakość życia mieszkańców starszych i z niepełnosprawnością.

Abstract

Demographic changes that can be notice in nowadays society are unprecedented: the population of our world has never before been increased so rapidly. What is more, an average life expectancy has never been so high. It is estimated that the group of seniors (persons over sixty years old) is about 500 million worldwide. Academics and demographers admit, that by 2050 the overall proportion of elderly is going to double, approaching over a one-fifth of the entire population.

Definitions of the smart city are numerous. Some of them focus mainly on technology aspects, while the others emphasize indicar of habints' quality of life (persons with disabilites as well) is a ming of this using. Hence, with great certainty it can be assumed that a smart city is equally an accessible for all and friendly city.

The aim of this paper is to analyse some of solutions and urban policies which are applying of modern smart cities. Characterised solutions directly affect the quality of life of the elderly and people with disabilities and accessibility of urban spaces. Stowa kluczowe: Projektowanie uniwersalne, projektowanie dla wszystkich, miasta inteligentne, smart city, miasta przyjazne starzeniu, Barcelona
Keywords: Universal design, access for all, smart city, age-friendly cities, Barcelona

\section{Miasto dziś}

Niemal każda współczesna publikacja poświęcona problematyce miast rozpoczyna się bezpośrednim odwołaniem do raportu ONZ', dotyczącego ciaghego wzrostu liczby ich mieszkancow. Wwy nku dokonujących się w ciągu ostatnich pięćdziesięciu lat procesow urbanizacyjnych juz teraz ponad połowa ludności świata mieszka w miastach, a do roku 2050

\section{Todays's City}

Practically every recent publication related to city issues sets off direct appealing to the United $\mathrm{Na}$ the number of urbanites. As a result of uncrease in processes going ahead since last fifty years half of the population lives in cities. What is more, it is estimated, that the number is going to increase and in liczba ta przekroczy $75 \%$ światowej populacji2. Według badan w Europie wskaznik urbanizacji w chwill obecnej wynosi niemal 75\%, przy czym szacuje się, ze w roku 2050 będzie to już $80 \%{ }^{3}$.

Wellington E. Webb, były burmistrz Denver, stwierdzit, że „wiek XIX był czasem imperiów, XX - wiekiem panstw narodowych, a wiek XXI będzie stuleciem miast" ${ }^{\prime \prime}$. Trudno się $z$ tym stwierdzeniem nie zgodzić. Już od kilku dekad bowiem miasto - jako przestrzen, zjawisko, produkt czy wreszcie scen dla spolecznych dzzlan - staje się przedmiotem badan wielu dziedzin, a nawet, niejednokrotnie, poligonem doswiadczalnym licznych koncepcji na temat jego przyszłego wyglądu. Analiza pojawiających się koncepcji staje się szczegönie ciekawa w kontekście miasta rozumianego jako odzwierciedlenie podstawowych wartości i zalezności w społeczeństwach, będącego równocześnie ich pierwszą wizytówką, zapisem przeszłości i przyszłych dążeń ${ }^{5}$

\section{Miasto inteligentn}

Koncepcja smart city odmieniana jest przez przypadki niemal w każdym aspekcie współczesnych badań nad miastem i w każdej z zajmujących się nim dziedzin, od urbanistyk poczawsszy a na socjologii czy psychologii miasta kończąc. Gdyby popularnośc tematu mierzyć ilością specjalistycznych interdyscyplinarnych konferencji, artykułów $\mathrm{w}$ prasie i pubIkacji ksiązkowych, zagadnienie miast inteligentnych z pewnością znalazłyby się w ścisłej czołówce najważniejszych zagaznon wspolczesnosci.

Rozznorodnosc definicji smart city jest bardzo duża: cechuje je równieź szeroki zakres rozłożenia akcentów: jedne z nich zwracają bowien szczegóna uwage na kwestie technologicze (okresle czasem jako uwade sman cily), in z koleinagadnich

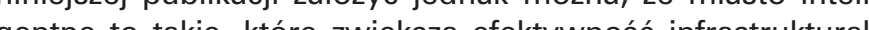
ni dzieki wykorzystaniu nainowszch technologil, przede

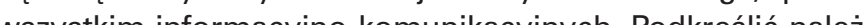
Jednak, ż aspekty technologiczne sa zaledwie jedna z wiey wetermin as bycia smart, a mista inteligu jed za zielu wistości te, które potrafia funkcjonować, sprawnie wprowadzajac innowio w sześciu kluczowych obszarach rozwoju: - konkurencyinośc ekonomicznej (economy competetivenes - kapitale spotecznym (social and human capital) - zarzadzaniu partycypacyjnym (governance e participation) - mobilności i transporcie (mobility \& transport) - kondycii środowiska naturalnego (natural resources) - jakości życia mieszkańców (quality of life) ${ }^{6}$.

Podstawowe czynniki, określające smart nych kluczowych obszarów rozwoju to: Jak już wcześniej wspomniano, w powszechnej świadomości smart city kojarzone jest przede wszystkim z rozwojem najnowocześniejszych technologii i inwestycjami w infrastrukture: systemy informatyczne (również te z obszaru big data), internet rzeczy czy choćby miejskie strefy darowego wi-fi. Wydaje się więc, że miasto w takim układzie dedykowane jest przede wszystkim precyzyjnie określonej grupie tzw. konsumentow czy mieszkańców cyfrowych (ang. connected consumer connected citizen) a w podstawowej koncepcji utożsamiane jest powszechnie z miastem cyfrowym.
2050 about $75 \%$ of all people worldwide is going to become acty dwellers. According to recentresearches, urbanisation rate in Europe amount to $75 \%$, but it has been
going to be over $80 \%^{3}$.

Whe former Mayor of Denver, Colorado, has asserted that "The 19th century was a century of empires, the 20 th century was a century of nation states. The 21 st century will be a century of cities ${ }^{\prime \prime}$. It is difficult to disagree with this statement. Already since a few decades a city - considered as a space, phenomenon, product or scene for social activities - beco
even

training ground for plentiful concepts about its ts about is cepts becomes particularly interested in the context of the city comprehended as a reflection of basic values and dependencies in societies: the first showcases, records of past and future aspirations

Smart City

idea of smart city has been raising in almost town planning to sociology and psychology of the city. If the popularity of the topic is measured by the number of specialized and interdisciplinary conferences, newspaper articles, books and publications, the issue of smart cities will certainly be in the forefront of the most important issues of the

The variety of smart city definitions is very large. It is also featured a wide range of emphasis: some of (sometimes called hard smart city), while others - to social matters (soft smart city). However, for the purposes of the article can be assumed the smart city as the one that improves infrastructure efficiency by using the latest technologies, especially information and communication technologies. Nevertheless, it needs to be highlighted, that the all technology aspects are just one of many deare those, that are able to function effectively by introducing innovations in six key areas of development:

- social and human capital;

governance \& participation;

- mobility \& transport

- natural resources;

The key factors determining smart city for each key development area are:

As has been mentioned earlier, in general, smart city is associated primarily with the development of the most progressive technologies and infrastructure investments: IT systems (including big
data areas), Internet of Things ${ }^{7}$ or even city hot data areas, Internet of Things ${ }^{7}$ or even city hot city in such a shape pretends to be mostly dedicat- 
Tab. 1. Kluczowe obszary rozwoju miast inteligentnych - poszzczególne czynniki determinujace smart city - opracowanie własne na podstawie:
Smart cities. Ranking of European medium-sized cities, s. 12 .

\begin{tabular}{|c|c|c|}
\hline Konkurencyjność ekonomiczna & Kapitał społeczny & Zarządzanie partycypacyjne \\
\hline $\begin{array}{l}\text { innowacyjność } \\
\text { przedsiębiorczość } \\
\text { wizerunek gospodarczy } \\
\text { wydajność } \\
\text { elastyczność rynku pracy } \\
\text { miejsce w gospodarce } \\
\text { międzynarodowej } \\
\text { zdolność adaptacji }\end{array}$ & 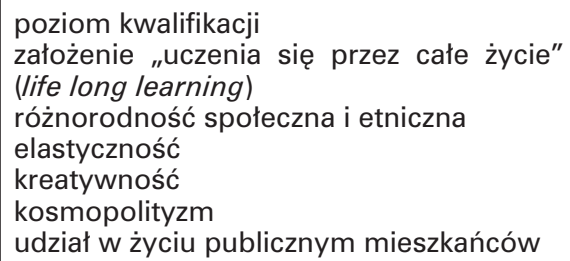 & $\begin{array}{l}\text { udział mieszkańców w podejmowaniu } \\
\text { decyzji } \\
\text { poziom usług publicznych i socjalnych } \\
\text { przejrzyste zarzadzanie miastem } \\
\text { długofalowe strategie polityczne i pers } \\
\text { pektywy rozwoju }\end{array}$ \\
\hline Mobilność i Transport & Środowisko naturalne & Jakość życia mieszkańców \\
\hline $\begin{array}{l}\text { lokalna i miêdzynarodowa } \\
\text { dostepność } \\
\text { dostepność struktur ICT'7 } \\
\text { zrownoważone, innowacyjne i bez- } \\
\text { pieczne systemy transportowe }\end{array}$ & $\begin{array}{l}\text { atrakcyjne warunki naturalne } \\
\text { poziom zanieczysczzenia środowiska } \\
\text { ochrona środowiska } \\
\text { zarzązanie zasobami odnawialnymi } \\
\text { (zrównoważona gospodarka zasobami) }\end{array}$ & $\begin{array}{l}\text { dostêp do kultury } \\
\text { warunki zdrowotne } \\
\text { jakośśśrodowiska zamieszkania } \\
\text { jakość i i wyposażenie obiektów eduka. } \\
\text { cyjnych } \\
\text { atrakcyjosćć turystyczna } \\
\text { integracja społeczności }\end{array}$ \\
\hline
\end{tabular}

Tab.1. Key areas for the development of smart cities - the various determinants of smart city - based on: Smart cities. Ranking of European
medium-sized cities, p. 12

\begin{tabular}{|c|c|c|}
\hline Economy (Competetiveness) & People (Social and Human Capital) & Governance (Participation) \\
\hline $\begin{array}{l}\text { Innovative spirit } \\
\text { Entrepreneurship } \\
\text { Economic image \& trademarks } \\
\text { Productivity } \\
\text { Fexibility of labour market } \\
\text { International embeddedness } \\
\text { Ability to transform }\end{array}$ & $\begin{array}{l}\text { Level of qualification } \\
\text { Affinity to life long learning } \\
\text { Social and ethnic plurality } \\
\text { Flexibility } \\
\text { Creativity } \\
\text { Cosmopolitanism / Openmindedness } \\
\text { Participation in public life }\end{array}$ & $\begin{array}{l}\text { Participation in decision-making } \\
\text { Public and social services } \\
\text { Transparent governance } \\
\text { Political strategies \& perspectives }\end{array}$ \\
\hline Mobility (Transport and ICT) & Environment (Natural Resources) & Living (Quality of Life) \\
\hline $\begin{array}{l}\text { Lokal accessibility } \\
\text { International accessibility } \\
\text { Availability of ICT-infrastructure } \\
\text { Sustainable, innovative and safe } \\
\text { Transport systems }\end{array}$ & $\begin{array}{l}\text { Attractivity of natural conditions } \\
\text { Polllution } \\
\text { Environmental protection } \\
\text { Sustainable resource management }\end{array}$ & \begin{tabular}{|l|} 
Cultural facilities \\
Health conditions \\
Individual safety \\
Housing quality \\
Education facilities \\
Touristic attractivity \\
Social cohesion
\end{tabular} \\
\hline
\end{tabular}

Co istotne, choć grupa cyfrowych konsumentów definiowana jest raczej behawioralnie niż demograficznie, charakterystyczna jest dla niej przewaga ludzi młodych $i$ aktywnych. Tymczasem aktualne badania pokazuja wyraźnie, że charakterystyczną cechą współczesnej cywilizacji jest znaczny wzrost długości życia ludności oraz zwiazzane z tym starzenie się społeczeństw oraz zwiększanie odsetka seniorów i osób z ograniczeniami w mobilności lub percepciji. Zmiany demograficzne, jakie możemy obecnie odnotować w społeczeństwie, mają bowiem charakter bezprecedensowy: jeszcze nigdy w historii liczba mieszkańców naszego świata nie powiększała się tak gwałtownie, a jednocześnie - średnia wieku ludności nie była tak wysoka.

Już w tym momencie grupa osób powyżej 60 roku życia to około 500 milionów w skali swiata, a demografowie szacuja ze pomiędzy rokiem 2015 a 2050 stosunek liczby seniorow do reszty populacji niemal się podwoi, wzrastając z $12 \%$ do $22 \%{ }^{\circ}$. Przy czym, co istotne, będzie to juź populacja licząca ok. 9,5 mld. Co więcej, wzrost długości życia przekłada się również na liczbę osób z niepełnosprawnoscią: według Światowego Badania Zdrowia na świecie żyje ponad 700 milionów osób z różnego typu dysfunkcjami, co stanowi ponad 15\% populacji Ziemi (przy czym róne zespoly badawcze podaja różne dane - badania Global Burden of Disease zakładają, że może być to nawet $19 \%{ }^{11}$ ). and aging population. This leads to the increase in the proportion of seniors and people with mobility or perceived limitations. Demographic changes edented: the population of our world has never before been increased so rapidly. What is more, an average life expectancy has never been so high. It is estimated that the group of seniors (persons over sixty years old) is about 500 million worldwide. the overall proportion of elderly is going to double, from $12 \%$ to $22 \%$ of the world's population'. What is extremely important, it is going to be the world's population of 9,5 billion. The increase in life expectancy also translates into the number of people with disabilities: according to the World Health Research,
Biorąc pod uwagę powyższe dane z dużym prawdopodobienstwem można więc zalożyc, że kwestia przystosowania przestrzeni miejskich do potrzeb wszystkich użytkowników - w tym równiez seniorów i osób z niepełnosprawnościa będzie jednym z kluczowych zagadnien terazniejszości i przyszłości; szczegolnie, ze stanowi ona takze istotną składow przynajmniej trzech spossrod szesciu kluczowych obszarów funkcjonowania miast inteligentnych: kapitału społecznego, mobilności i transportu oraz jakości życia.

\section{Miasto dostępne}

Jedną z wielu prób odpowiedzi na aktualne i prognozowane zmiany demograficzne stał się opublikowany w 2007 roku przez Swiatową Organizację Zdrowia (WHO) Przewodnik po Miastach Przyjaznych Starzeniu. Jednym z głównych zawartych w nim postulatów jest wspieranie tzw. aktywnego starzenia się w miejscu, czyli konkretnych warunków, po których spełnieniu „mieszkańcy miast są w stanie żyć samodzielnie we własnym domu i społeczności - bezpiecznie, niezależnie i wygodnie, bez względu na wiek, dochody lub indywidualne możliwości poszczéólnych ludzi (. . ")"12.

Chociaż koncepcja miast przyjaznych starzeniu powstała niezależnie od idei miast inteligentnych, nie da się nie zauważy pewnych wspólnych dla nich założeń. Współczesne pojęcie aktywnego starzenia bazuje na przekonaniu, wedle którego ludzie mają prawo uczestniczyc we wszystkich aspektach życia spolecznego zgodnie ze swoimi moźliwościami, niezależnie od osobistych ograniczeń. Bezpośrednim celem strategii aktywnego starzenia się jest - na poziomie indywidualnym - podnie-

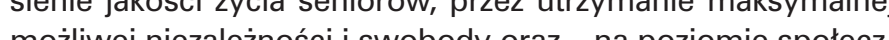
moż - zmniejzznie wydatków publicznych, zwi zpoleczśm - zmniejszenie wydák publcznch, związanych ze

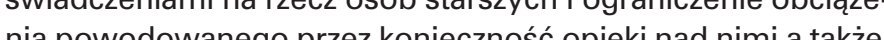
co nie mniej ważn popularyzowanie tzw. solidaności me

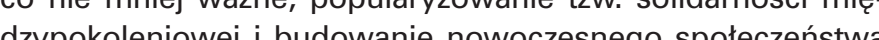

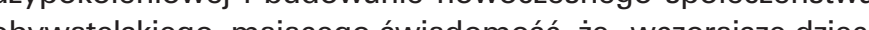
a dzisiejs doró́l a jutrzesi dziad

W opublikowanych wytycznych Swiatowa Organizacja Zdrowia wyznacza osiem podstawowych obszarów tematycznych, w których realizowane muszą być konkretne działania, zmierzające do stworzenia miasta przyjaznego osobom starszym (a co za tym idzie - w myśl idei projektowania uniwersalnego - również osobom z niepełnosprawnością). Są to:

- przestrzenie i budynki,

transport, mieszkalnictwo

- partycypacja społeczna, more than 700 million people live with various dysfunctions, what represents over $15 \%$ of the world's population (different researchers have been reporing different data, the Global Burden of Disease study assumes that number up to $19 \%$ )

The aptation to the needs of all users (including elderly and persons with handicap) is going to be one of the most crucial questions of the present and the future. In particular, it is also an important component of at least three of the six key areas of smart capital, mobility \& transport and quality of life.

\section{Accessible City}

One of many attempts to respond to current and forecast demographic change has become a WHO A Guide. One of the main demands placed on it is to sup port the so-called. Active aging in place, ie speare conditions after which to meet " city dwellers and community - safely, independently and conveniently, regardless of their age, income or individual capacity"

Although the concept of age-friendly cities has emerged independently of the idea of smart citles, it is impossible to overlook some common assumptions. The contemporary concept of active aging is based on the belief that people have according to their capabilities and rociless of personal limitations. The direct objective of active aging strategies is:

on an individual level: to improve the quality of life for seniors by maintaining the maximum possible independence and discretion; and

tsocial level: reducing public expenditure relate to benefits to the elderly, minimalizing the burde of care and - what is extremely important - popuing a modern civil society, aware that "yesterday's children are today's adults and tomorrow's grandparents"

In published guidelines, the World Health Organ zation identifies eight basic thematic areas where specific actions need to be taken to create a city that is friendly to the elderly (and consequently to - also for people wit disabilities). These are: 


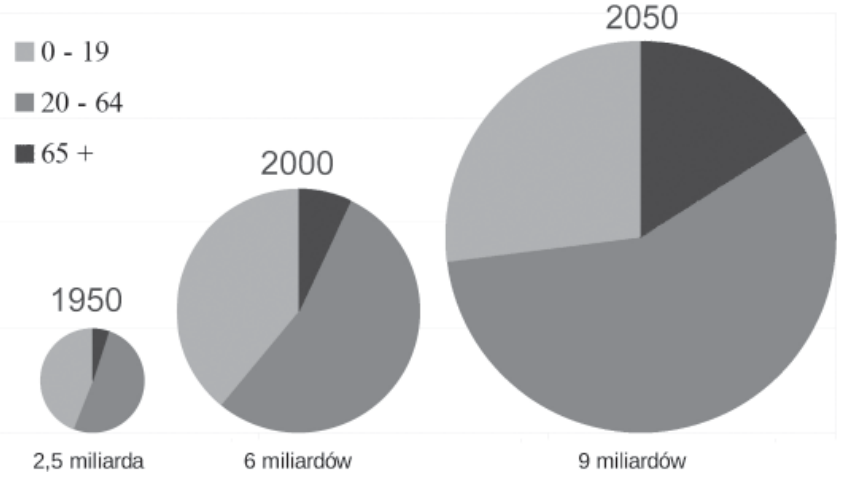

- wzajemny szacunek i aktywność społeczna

\section{- zatrudnienie,}

- komunikacja i informacja

- pomoc socjalna,

Wszystkie te zagadnienia nakładaja sie na siebie i sa od siebie współzależne, chociaż poruszają kwestie związane zarówno z bezpośrednim, fizycznym otoczeniem, jak i środowiskiem społecznym oraz aspektami zdrowotno-socjalnymi. Wszystkie również wpisują się $w$ zakres wymienionych wcześniej sześciu kluczowych obszarów rozwoju miast inteligentnych: Koncepcja miast przyjaznych starzeniu odnosi sie do i ch: w ramach którego mieszkańcy miast sa w stanie żyć samodzielnie we własnym domu i społeczności- bezpiecznie, niezależie i wygodnie, bez wzgledu na wiek, dochody lub indywidualne możliwości poszczególnych ludzi; moga mieszać w domu tak długo, jak to jest możliwe, zamiast żyć w domach opieki"14. Co istotne, kluczowe działania, realizowane $w$ ramach głównych obszarów tematycznych miast przyjaznych starzeniu realizowane sa poprzez rozwiazania typowe dla miast inteligentnych: za pomoca nowoczesnych technologii $\mathrm{z}$ zakresy twardego smart city oraz poprzez wprowadzanie z zakresy twardego smart city oraz poprzez wprowadzanie
działań podnoszacych poziom bycia smart w obszarach miękkich: kapitału społecznego, warunków zdrowotnych i ogólnej jakości życia (por. tab. 1).

\section{Planowanie systemowe: miasto inteligentne -}

miasto dostępne

Nie można zaprzeczyć, że jakość życia mieszkańców, należącego do kluczowych elementów miast inteligentnych, stała nia miejskich przestrzeni publicznych - nie tylko przez specja-

Tab. 2. Correlation of the core thematic areas of age-friendly cities and key areas of smart cities

\begin{tabular}{|l|l|l|}
\hline \multicolumn{1}{|c|}{ Economy (Competetiveness) } & People (Social and Human Capital) & \multicolumn{1}{|c|}{ Governance (Participation) } \\
\hline $\begin{array}{l}\text { employment } \\
\text { social service }\end{array}$ & $\begin{array}{l}\text { social participation } \\
\text { respect \& social inclusion } \\
\text { communication \& information } \\
\text { social service }\end{array}$ & $\begin{array}{l}\text { social participation } \\
\text { reciprocal respect \& social activity } \\
\text { communication \& information }\end{array}$ \\
\hline \multicolumn{1}{|c|}{ Mobility (Transport and ICT) } & Environment (Natural Resources) & \multicolumn{1}{c|}{ Living (Quality of Life) } \\
\hline $\begin{array}{l}\text { outdoor spaces and buildings } \\
\text { transportation \& housing }\end{array}$ & $\begin{array}{l}\text { outdoor spaces and buildings } \\
\text { transportation \& housing }\end{array}$ & $\begin{array}{l}\text { outdoor spaces and buildings } \\
\text { transportation \& housing } \\
\text { communication \& information } \\
\text { social service } \\
\text { community support and health services }\end{array}$ \\
\hline
\end{tabular}

listów, ale przede wszystkim przez użytkowników. Badania's 85\% mieszkańców ma śladomośc bezpośredniego wplyw jakości przestrzeni publicznej na samopoczucie jej użytkownikow i potencjalny rozwoj ich moz dań ${ }^{16}$ aż $69 \%$ mieszkańców miast chcialoby miec możliwośc zgłaszania pomysłow na elementy, funkcje, usługi smart city $w$ ich miastach, przy czym, co ciekawe, w grupie wiekowe 55-64 odsetek osób zainteresowanych wyniósł 77\% a w grupie $>64-46 \%{ }^{17}$

Udział społeczności $\mathrm{w}$ budowaniu miasta inteligentnego jest jednym z kluczowych aspektów, idea smart city zakłada bowiem, ze ma byc ono bezpleczne, funkcjonalne i przyjazne dla wszystkich mieszkańców. Zmiany demograficzne w znacznym stopniu wymuszają przeobrażenia w obrębie zarówno miejskiej infrastruktury (szersze, wygodne ciągi piesze, bezpieczne oświetlenie, dostępność przestrzen publicznych itp.), jak i samej społeczności mieszkańców (przeciwdziałanie wykluczeniu osób starszych i z niepełnosprawnościa, integracja międzypokoleniowa, zapewnienie pełnego dostępu do wydarzeń kulturalnych wszystkim osoom zainteresowanym).

W krajach Europy Zachodniej, co szczególnie istotne, ogromna większość, jeśli nie wszystkie z podejmowanych działań, mają charakter strategiczny: tworzone są długoletnie plany systemowe, nie realizuje się natomiast pojedynczych, odewanych od siebie inicjatyw. Pelna dostępnosc miasta i przystosowanie jego przestzeni do potrzeb wszystkich użytkownoww jest bowiem wynikową dostępności trzech kluczowych sekow: przestzeni publiczej, budynków (szczegolnie - budynow uzytecznosci publicznej) oraz transportu - czeW prakty se oznacza to zaiec, że koniczze jest opracolan.

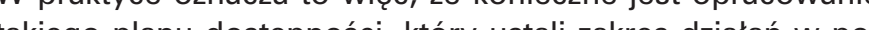
take planu dostępnosci, kóry ustall zakres dzlalan w pocoodynacie tych dziań (np. przez powolanie stanowisk

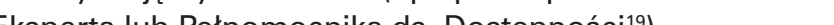

Nie dziwi, że większość ośrodków, które odniosły na tym polu sukces, najpierw wypracowała, a potem wdrażała autorskie plany budowania dostępności, będące również budowaniem ich wizerunku jako smart city. W całym procesie charakterystyczna była więc $z$ jednej strony etapowość realizacji, z drugiej - konsekwentne współdziałanie interdyscyplinarnych zespołów do spraw planowania dostępności, w których skład wolów do spraw pla prowstawiciele samorzadów i sładz miejskich, architekci i urbaniści, jak również grupy ekspertów i osób z niepełnosprawnościa oraz seniorów. W przypadku budowania miasta inteligentnego i dostepnego kluczowa jest bowiem zasada partycypacji i samostanowienia poszczególnych grup użytkowników przestrzeni miejskich.

\section{Case study: Barcelona}

Na kwestię pełnej dostępności miasta i przystosowania jego przestrzeni do potrzeb wszystkich użytkowników bezpośredni wpływ mają niemal wszystkie spośród możliwych działań wchodzacych w zakres koncepcji smart. Jednak, co oczywiste, niektóre z budują dostępność pośrednio - tak jak systemy inteligentnego parkowania, sieci darmowego wi-fi itp. - inne natomiast bezpośrednio poprawiaja bezpieczeństwo i kom fort użytkowania przestrzeni przez osoby z niepełnosprawnością i seniorów. public space on the well-being of their users and their potential personal development. On the other hand - according to research ${ }^{15}$ as many as $69 \%$ of city habitants would like to be able to submit ideas in their cities, but in the age grmap $55-64$, the proportion of people concerned was $77 \%$ and in the group $>64-46 \% \%^{16}$.

Community involvement in smart city establishing is one of the key aspects, as the smart city's idea is to be safe, functional and user-friendly. Demographic changes are largely driven the transformations within both urban infrastructure (wider, comfortable walking routes, safe lighting pity itself (cos teracting exclusion of the elderly and persons with disabilities, intergeneration integration, full access to cultural events for all interested persons).

opean countries the vast majority (if not all) of the actions that has been undertaken, has got a strategic nature: long-term systemic phe are not implemented 17 . It is transpiring that be Iy public spaces are the result of acessibility in three key sectors: public space, buildings (especially public buildings) and transport. And that cannot be solved by short-term actions. In practice, this means that it is necessary to develop an availability plan that sets the scope of activities in each sector and will be able to coordinate thes activities (eg by establishing an Access Officer ppointment ${ }^{18}$

There is no surprise that most of the cities that oped and then implemented their own dever bility plans, which have also build their images as a smart cities. In the whole process the characteristic were step by step implementation and consistent cooperation of interdisciplinary panels of experts of accessible planning that incorporated representatives of local governments and municipalties, architects and planners and expert obvious then that in case of building a smart It accessible city, the principle of participation and self-determination of individual groups of urban space users is crucial.

Case study: Barcelon

Co by almost all of the possible activities falling with the scope of the smart concept. However, of course, some of those create an accessibility indirectly llike smart parking systems, free wi-fi networks, etc. while others directly improve the safety and comfort of life of people with disabilities and seniors. All of the solutions below have been recently im sen by no accident: in the Juniper Research 2015 Barcelona occupied first place among the smartest cities in the world (Global Smart City Research) overtaken New York, London, Nice and Singapore. In the ranking of the next year it was in the sec- 
Wszystkie przedstawione poniżej rozwiązania realizowane są obecnie na terenie Barcelony. Miasto to zostalo wybrane nieprzypadkowo: W rankingu Juniper Research z roku 2015 Barcelona zajęła pierwsze miejsce wśród najbardziej inteligentnych miast swiata (Global Smart City), wyprzedzając kolejno Nowy Jork, Londyn, Niceę oraz Singapur; w rankingu $z$ roku kolejnego znalazla się natomiast na drugim miejscu, ustępując jedynie Singapurowi $i^{20}$. Co równie ważne, Barcelona jest także jednym z pierwszych miast europejskich opracowujących i realizujących długofalowe koncepcje budowania dostępności (w ramach Miejskich Planów Dostępności na lata 1995-2006 i 2007-2011).

Poza szeregiem działan $w$ obszarach ochrony środowiska ${ }^{21}$ i zrównoważonego transportu miejskiego, charakterystyczny dla Barcelony jest duży nacisk kładziony na programy społeczne i socjalne ${ }^{22}, w$ tym również te $z$ nich, które są kierowa bezpośrednio do seniorów $\mathrm{i}$ osób z niepełnosprawnością,

Telecare jest bezpłatną, całodobową usługą pomocy w sytuacjach kryzysowych, skierowaną do osób starszych, samotnych i z niepetnosprawnoscią, a takze wszystkich tych, którzy takiej pomocy moga wymagac. Osoba potrzebująca pomocy, po aktywacji przycisku znajdującego się $w$ jej domu, tączy się bezpostednio z zespolem call center, ktory - wraz z gronem specjalistów - pomaga rozwiązywać konkretne problemy: "mogą pomóc w zlokalizowaniu członków rodziny lub wyznaczonych kontaktow, wysłać jednostkę mobilna do domu użytkownika lub angazują inne služby ratownicze ne, pracow ucy Telecieja dzilają taky ra w zakresie prewencji, utrzymując staly kontakt $z$ osobami, dotkniętymi problemem

Rostał stworzony z myślą o poprawie jakości życia osób starszych, przy czym jego działanie nie opie-

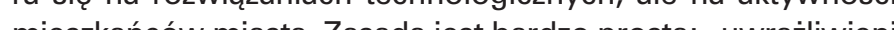
na mieszkajacy w poblizu starszych ludzi mieszk ricy-radary gdy zauzża niepokoiace sygnały lub zmiany, moga zglosić je przez tefon lub e-mil do centrum ustug socjog z" mach prowadzonych interwencii do senióńw delegowan sa procownicy socjani lub wolontariusze, których zadaniom jest albo konkretna pomoc, albo też spedzanie czasu z oso-

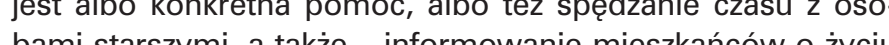
społeczności i nowych usługach dostepnych lokalnie).

Przejrzystość i dostępność urzędników miejskich jest jed nym z filarów miesta inteligentnego, dlatego też nezwyk istotnym iest uwzglednienie zangażonania spoteczeństwa w projekty admingtracyine miasta. Wszystkie inicjatywy tworzone sa wiec w sposób zapewniajacy mieszkańcom wyrażenie swojej opinii oraz przedstawienie własnych propozycii. Element ten wydaje sie o tyle istotny, że w grupie seniorów czy osób z niepełnosprawnościa czesste jest prześwianiorow o marginalizowaniu ich roli oraz problemach z komunikacia $z$ władzami miejskimi2

Co równie istotne, w ramach programu Barcelona Open Government (wraz z towarzyszacą mu aplikacją Citizens' Postbox, służąca do przesyłania w czasie rzeczywistym informacji o konkretnych incydentach w mieście) stworzona została elektroniczna platforma dla obsługi administracyjnej, która umożliwia komunikacje z przedstawicielami miasta, wyrażenie opinii przez mieszkańców oraz ocene polityki miejskiej. Choć wydawać by się mogło, że tego rodzaju działania nie ond place, going down only to Singapore ${ }^{19}$. What first European cilies to develop and implement long-term accessibility plans (within the framework of the Urban Accessibility Plans for 1995-2006 and
2007-2011).

In addition to a number of activities in the field of transportation, the most characteristic for BarceIona is a great emphasis places on social and social programs $\mathrm{s}^{21}$, including those that are directed directly to elderly and people with disabilities.

Telecare is a free, 24 hour emergency assistance service for the elderly, lone and disabled, and all vates the may need help. The person in need actirectly to the call center team, which, together with a group of specialists, help solve particular problems: hey can help to find or locate family members or designated people, send a mobile unit to one's home or engage other emergency services ${ }^{2}$. Significantly, Telecare employees also work on prevention, maintaining constant contact with people affected by isolation and lonelines

Also, the Radars project was designed to improv not based on technological solutions but on the activity of the city residents.

The idea is very simple: responsive people living nearby elderly people (called "radars") when noticed disturbing signals or changes, report it by phone or email to the social services center ${ }^{24}$. As part of the intervention for seniors, social workers or volunteers are dispatched either to help, or to spend time with the elderly, and to inform the new services available locally.

The transparency and openness of city officials is one of the pillars of a smart city, and it is therefor extremely important to include the involvement the public in the city's administrative projects. Al initiatives are created in such a way as to ensure that residents express their views and present their proposals. This element seems so important tha frequent is belief of marginalization of their rolite and problems with communication with municipa authorities ${ }^{25}$.

As a part of the Barcelona Open Government Programme (along with the accompanying Citizen Postbox application, which provides real-time information about specific incidents in the city) has been created an electronic administrative support platform that enables communication with city repevaluating urban policy. While it may seems that such activities do not have a direct impact on the quality of life of people with disabilities and elderly, in practice, it appears that the ability to remotely deal with specific matters at the office is critical for many people with limited mobility or communication problems.

The current demographic change process: unprecedented population growth combined with a sharp mają bezpośredniego wpływu na wzrost jakości zycia osob możliwośc go) załatwienia konkretnych spraw w urzędzie jest kluczow dla wielu osób o ograniczonej mobilności czy problemach $w$ porozumiewaniu sie.

\section{Podsumowanie}

Obserwowany aktualnie proces zmian demograficznych: niespotykany wcześniej wzrost populacji wraz z gwattownym wzrostem sredniej wieku stanowi jedno z wyzwan dla wspólczesnego i przyszlego ksztaltu miast - stą tez przekonanie coraz większej grupy specjallistów o koniecznosci wypracowania nowych gaz dziej dostępnych i przyjaznych.

Udział społecznosci miejskich w budowaniu nowych, intelgentnych miast jest kluczowe dla stworzenia bezpiecznych ifunkcjonalnych przestrzeni - dlatego też, poza wykorzy stywaniem technologii z zakresu tzw. twardego smart city, szczególnie istotne jest budowanie międzypokoleniowego poczucia wspolnoty - i taka tez koncepcja wydaje się byc najlepszą dla stworzenia ram polityki przestrzennej współczesnych miast inteligentnych, szczegolnie, ze "miejsca przyjazn seniorom są jednoczesnie przyjazne dla rodziców $z$ dziećm niepełnosprawnych, czyil luzi w kazdym wieku'

Przykłady rozwiązan systemowych wprowadzanych w Barcelonie - mieście znajdującym się równocześnie w czołówce rankingow smart clles i miast dostępnych - moga stano-

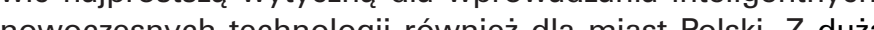
nowoczesnych techologî rownież dla miast Polski. $Z$ duża pewnosią zalożć bowi low nym i prayjanym dla wszystich swoich mieszkańców i uży-

PRZYPISY

United Nations, Department of Economic and Social Affairs (UNDESA), dostęp
(U)

BBVA Research - Urbanization report European Urbanization Trends.

Cyt. za: M. Florek: Idea smart w brandingu.... s. 89
Por.:. G. Gyurkovich: W poszukiwaniu d... S. 131

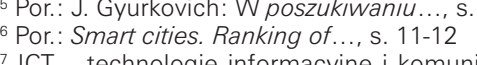

ICT - technologie informacyine i komunikacyine lang. Information and Com

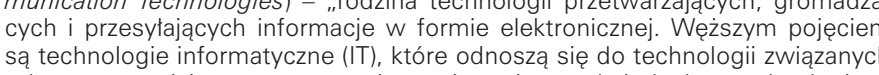
sa technologie informatyczne
$z$ komputerami i oprogramowaniem, nie zwiazanych jednak z $z$ technologiam

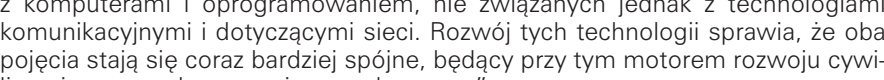

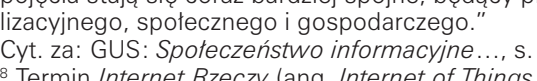

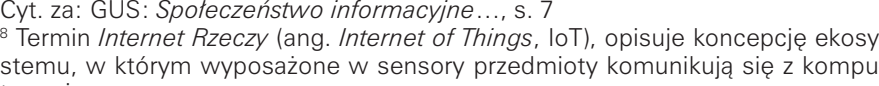
stemu, w którym wyposażone w sensory prze
terami.
Por.: P. Kalenda (red.): Raport: Internet..., s. 3

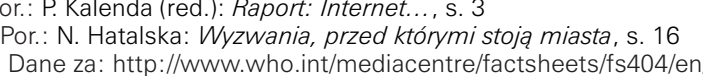

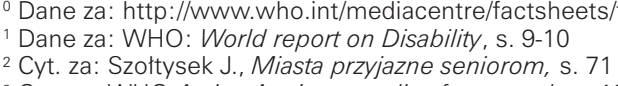

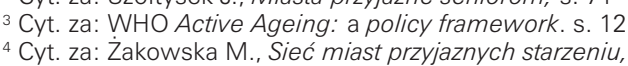

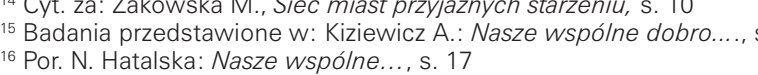

17 Por.: tamze
18 Por.: N. Hatalska: Inteligentne miasto..., 42

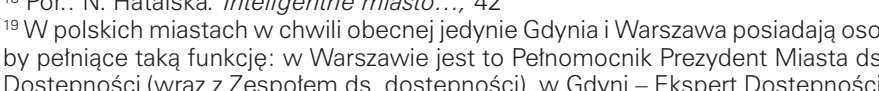

rise in average birth rates is one of the most important challenges for today's and future cities. This situation entails the conviction of an increasing number of specialists on the need to develop new solyCity communities participation in the process creating smart cities is crucial for creating safe and functional spaces. Therefore, in addition to the use of technology of the so-called hard smart city", it is especially important to build an intergenerationa sense of community. This concept seems to be ultimate for possibility of creating a spatial policy framework for modern smart cities, especially "friendly places for seniors are also friendly to parpeople of all ages" 26 .

Examples of system solutions introduced in Barce- a city at the top of the ranking of $\mathrm{sm}$ Barceand cities available - may be the simplest guideline for introducing intelligent, modern technologies also for Polish cities. With great certainty, can be assumed that modern and future intelligen city must sintlaneously be a cily accessible and d users of space.

ENDNOTES

United Nations, Department of Economic and Social Af-
fairs (UNDESA), online access: http://www. unicef.org Sowc2012//urbanmap/
2 Datas acc. to: United Nations, Department of Economic
and Social Affairs (UNDESA) online access: http://www

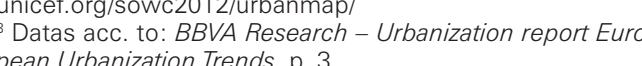
Acc. to: IBM Institute for Business Value: A vision of smar ter cities, p. 12
5 Acc. to: 1. Gyurkovich: W poszukiwaniu,..., p. 13
6 P Internet of Things, lot - is the inter-networking of physical devices, vehicles, buildings, and other items-embedde
with electronics, software, sensors, actuators, and network
connectivity that enable these objects to collect and exchange data.
Acc. to: thtps://en.wikipedia.org/wikillnternet of things
B Acc. to.: N. Hatalska: Wyzwania, przed któnymi stoja mia9 Dantas acc. to: http: ///www.who.int/mediacentre/factshe-
9 ts/fs404/en/

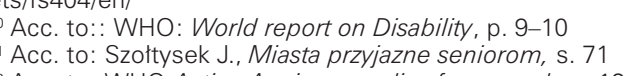

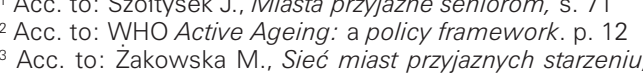
Research characterized in: Kiziewicz A. Nasze wspólne ${ }^{15}$ N. ...... p.lalka: Nasze wspólne...., p. 17
${ }^{16} \mathrm{~N}$. Hatalska: Nasze wspólne..., p. 17 "Por: N. Hatalska: Inteligentne miasto..., 42 18. In Poland, at present, only Gdynia and Warsaw have such
officials: in Warsaw it is President of the City's A gent of
Accessibility (together with the Accessibility Group). in Gdynia - Access Officer.
IAcc. to: htps://www.juniperresearch.com/press/press -releases//barcelona-named-global-smart-city-2015 and
https://www.juniperresearch.com/2ress/press-releases/ 20 The city has taken actions in the field of: efficient water
management (the "Smart Water" program), energy selfsufficiency (the "Solar Thermal Ordinance"), the creation
of a waste management system la selective collection network and green points- waste collection points for re-
cycling) or the pursuit of efficient, sustainable urban manaement (the BUITS Plan), that is including the use of aban-
oned or undeveloped areas in the center. (acc. to: N. Hatalska: Inteligentne miasto.... p. 52-54)
21 Presented examples of particular actions are, what is
obvious, only small (but still representative) - excerp of the 
20 Por: https://www.juniperresearch.com/press/press-releases/barcelona-named-global-smart-city-2015 oraz https://www.juniperresearch.com/press/press-releases/singapore-named-global-smart-city-2016

${ }^{21}$ Miasto podjęło działania w zakresie $\mathrm{m}$. in. efektywnego gospodarowania zasobami wodnymi (program Smart Water), samowystarczalności energetycznej (Solar Thermal Ordinance), stworzenia systemu gospodarki odpadami (siec kontenerów selektywnej zbiórki oraz tzw. zielonych punktów - punktów odboru odpadów do recyklingu) czy dążenia do efektywnego, zrównoważonego gospodarowania przestrzeniami miejskimi (plan BUITS) - w tym przede wszystkim wykorzystania porzuconych lub niezagospodarowanych obszarów w centrum. Por.: N. Hatalska: Inteligentne miasto..., s. 52-54

22 Przedstawione przykłady konkretnych działań, co oczywiste, stanowia jedynie niewielki - choć reprezentatywny - wycinek możliwości, jakie generuja najnowsze technologię wykorzystywane dla poprawy dostępności przestrzeni miejskich Barcelony.

${ }^{23}$ Cyt. za: N. Hatalska: Inteligentne miasto.... s. 56-57

24 Por.: tamże

${ }^{25}$ Cyt. za: tamże, s. 57

${ }^{26}$ Por.: N. Hatalska: Wyzwania, przed którymi..., s. 17

27 Cyt. za: P. Kubicki, Polska 2015 - kraj dla ludzi starych, dostęp online: http:// liberte.pl/polska-2015-kraj-dla-ludzi-starych/, data cytowania: 17.04.2017

\section{LITERATURA:}

[1] Błaszak M., Przybylski Ł.: Rzeczy są dla ludzi. Niepełnosprawność i idea uni wersalnego projektowania, Wydawnictwo Naukowe Scholar, Warszawa 2010

[2] Cieślak K.: Wieccej niż technologia [w:] Biblioteka wizerunku miasta, cz. 8. Smart City, s. 80-82

[3] Florek M.: Idea smart w brandingu miasta [w:] Biblioteka wizerunku miasta cz. 8. Smart City, s. 89-92

[4] Grabowska-Pałecka H.: Niepełnosprawni w obszarach i obiektach zabytkowych Problemy dostępności, Wydawnictwo Politechniki Krakowskiej, Kraków 2004 [5] Gyurkovich J.: W poszukiwaniu miejskości - przestrzeń przyjazna [w] Czasopismo techniczne. Architektura, 2-A/2010, z. 5, rok 107, Wydawnictwo PK, Kraków 2010, s. 131-144

[6] Hatalska N.: Inteligentne miasto planowane czy modernizowane [w:] Bibliote ka wizerunku miasta, cz. 8. Smart City, s. 41-57

[7] Hatalska N.: Wyzwania, przed którymi stoja miasta [w:] Biblioteka wizerunku miasta, cz. 8. Smart City, s. 11-17

[8] Kiziewicz A.: Nasze wspólne dobro, nasza przestrzeń publiczna, [w:] C.H. Beck Nieruchomości - styczeń 2013, dostep online: http://pfsrm.pl/sites/default/files/A \%20Kiziniewicz\%20-\%20NASZE\%20WSP\%C3\%93LNE\%20DO BRO 10.2012 0.pdf, data cytowania: 17.04.2017

[9] Magdziak-Grabowska M.: Wspótczesne technologie a komfort życia osób starszych [w] Czasopismo techniczne. Architektura, 2-A/1/2011, z. 11, rok 108, Wydawnictwo PK, Kraków 2010, s. 133-140

[10] Kalenda P. (red.): Raport: Internet rzeczy w Polsce, Interactive Advertising Bureau, dostęp online: https://iab.org.pl/wp-content/uploads/2015/09/RaportInternet-Rzeczy-w-Polsce.pdf, data cytowania: 17.04.2017

[11] Szołtysek J.: Miasta przyjazne seniorom, [w:] Słodczyk J., (red.), Studia miejskie, tom10, Opole 2013, s. 67-75

[12] Wejchert K.: Elementy kompozycji urbanistycznej, Wydawnictwo Arkady, Warszawa 1984

[13] Żakowska M.: Sieć miast przyjaznych starzeniu. Wywiad z Kristine Goulding, [w: Miasta, nr 2/2013, s. 9-14

[14] BBVA Research - Urbanization report European Urbanization Trends, s. 3, dostep online: https://www.bbvaresearch.com/wp-content/uploads/2016/12/ European-urbanization-trends_.pdf, data cytowania: 17.04.2017

[15] Społeczeństwo informacyjne w Polsce. Wyniki badań statystycznych z lat 2006-2010, Główny Urzad Statystyczny w Szczecinie, Warszawa 2010, dostęp online: http://stat.gov.pl/cps/rde/xbcr/gus/nts_spolecz_inform_w_polsce_2006-2010.pdf, data cytowania: 17.04.2017

[16] Smart cities. Ranking of European medium-sized cities, Centre of Regional Science, Vienna UT, October 2007, dostep online: www.smart-cities.eu/download/smart_cities_final_report.pdf, data cytowania: 15.04.2017

[17] Smart Londoñ Plañ, dostęp online: https://www.london.gov.uk/sites/default/ files/smart london_plan.pdf, data cytowania: 20.04.2017

[18] Stan Zdrowia Ludności Polski w 2009, Zakład Wydawnictw Statystycznych, Warszawa 2011

[19] WHO: Active Ageing: a policy framework. Genewa 2002, dostęp online: http://apps.who.int/iris/bitstream/10665/67215/1/WHO_NMH_NPH_02.8.pdf data cytowania: 20.04.2017

[20] WHO: World report on Disability, Malta 2011, dostęp online: http://www. who.int/disabilities/world_report/2011/report/en/, data cytowania: 17.04.2017

[21] http://www.who.int/en/, data cytowania: 17.04.2017 possibilities that are generated by the latest technology used to improve the accessibility of Barcelona's urban spaces.

22 Acc. to: N. Hatalska: Inteligentne miasto..., p. 56-57

${ }^{23}$ Acc. to: N. Hatalska: Inteligentne miasto..., p. 56-57

${ }^{24}$ Acc. to: N. Hatalska: Inteligentne miasto.... p. 57

${ }^{25}$ Acc. to: N. Hatalska: Wyzwania, przed którymi..., p. 17

${ }^{26}$ Acc. to: P. Kubicki, Polska 2015 - kraj dla ludzi starych, online access: http://liberte.pl/polska-2015-kraj-dla-ludzi-starych/

\section{BIBLIOGRAPHY:}

[1] Błaszak M., Przybylski Ł.: Rzeczy sa dla ludzi. Niepełnosprawność i idea uniwersalnego projektowania, Wydawnictwo Naukowe Scholar, Warszawa 2010

[2] Cieślak K.: Więcej niż technologia [in:] Biblioteka wizerunku miasta, cz. 8. Smart City, p. 80-82

[3] Florek M.: Idea smart w brandingu miasta [in:] Biblioteka wizerunku miasta, cz. 8. Smart City, p. 89-92

[4] Grabowska-Pałecka H. Niepełnosprawni w obszarach i obiektach zabytkowych. Problemy dostepności, Wydawnictwo Politechniki Krakowskiej, Kraków 2004

[5] Gyurkovich J.: W poszukiwaniu miejskości - przestrzeń przyjazna [in:] Czasopismo techniczne. Architektura, 2-A/2010, issue 5, year 107, Wydawnictwo PK, Kraków 2010 , p. $131-144$

[6] Hatalska N.: Inteligentne miasto planowane czy modernizowane [in:] Biblioteka wizerunku miasta, vol. 8. Smart City, p. $41-57$

[7] Hatalska N.: Wyzwania, przed którymi stoją miasta [in:] Biblioteka wizerunku miasta, vol 8. Smart City, p. 11-17

[8] Kiziewicz A.: Nasze wspólne dobro, nasza przestrzeń publiczna, [in:] C.H. Beck Nieruchomości - styczeń 2013 online access: http://pfsrm.pl/sites/default/files/A.\%20Kiziniewicz\%20-\%20NASZE\%20WSP\%C3\%93LNE\%20DOBRO 10.2012 0.pdf, date of quotation: 17.04.2017

[9] Magdziak-Grabowska M.: Wspótczesne technologie a komfort życia osób starszych [w] Czasopismo techniczne. Architektura, 2-A/1/2011, issue 11, year 108, Wydawnictwo PK, Kraków 2010, p. 133-140

[10] Kalenda P. (red.): Raport: Internet rzeczy w Polsce, Interactive Advertising Bureau, online access: https://iab.org. $\mathrm{pl} / \mathrm{wp}$-content/uploads/2015/09/Raport-Internet-Rzeczy-w-Polsce.pdf, date of quotation: 17.04.2017

[11] Szołtysek J.: Miasta przyjazne seniorom, [w:] Słodczyk J., (red.), Studia miejskie, vol.10, Opole 2013, p. 67-75

[12] Wejchert K.: Sieć miast przyjaznych starzeniu. Wywiad z Kristine Goulding, [in:] Miasta, nr 2/2013, p. 9-14

[13] Żakowska M.: Sieć miast przyjaznych starzeniu. Wywiad z Kristine Goulding, [w:] Miasta, nr 2/2013, s. 9-14

[14] BBVA Research - Urbanization report European Urbanization Trends, s. 3, online access: https://www.bbvaresearch.com/wp-content/uploads/2016/12/European-urbanization-trends .pdf, date of quotation: 17.04.2017

[15] Społeczeństwo informacyjne w Polsce. Wyniki badań statystycznych z lat 2006-2010, Główny Urząd Statystyczny w Szczecinie, Warszawa 2010, online access: http:/ stat.gov.pl/cps/rde/xbcr/gus/nts spolecz inform w polsce 2006-2010.pdf, date of quotation: 17.04.2017

[16] Smart cities. Ranking of European medium-sized cities, Centre of Regional Science, Vienna UT, October 2007, online access: www.smart-cities.eu/download/smart cities final report.pdf, date of quotation: 15.04.2017

[17] Smart London Plan, dostęp online: https://www.london. gov.uk/sites/default/files/smart Iondon plan.pdf, data cytowania: 20.04.2017

[18] Stan Zdrowia Ludności Polski w 2009, Zakład Wydawnictw Statystycznych, Warszawa 2011

[19] WHO: Active Ageing: a policy framework. Genewa 2002, online access: http://apps.who.int/iris/bitstream/10665/67215/1NHO_NMH_NPH_02.8.pdf, date of quotation: 20.04.2017

[20] WHO: World report on Disability, Malta 2011, online access: http://www.who.int/disabilities/world_report/2011/ report/en/, date of quotation: 17.04.2017

[21] http://www.who.int/en/, date of quotation: 17.04.2017 